\title{
Amyand's Hernia: an Up-to-Date Review of the Literature
}

Dimitrios Patoulias $^{1, *}$, Maria Kalogirou², Ioannis Patoulias ${ }^{2}$

\section{ABSTRACT}

Amyand's hernia is defined as an inguinal hernia, containing the appendix within the hernia sac. Incidence of this rare condition rises up to $1 \%(0.19-1.7 \%)$ of all inguinal hernia cases. Inflammation of the appendix within the inguinal sac is even rarer, as it corresponds to $0.1 \%$ (0.07-0.13\%) of all Amyand's hernia cases. After a comprehensive review of the limited relevant literature, we aim through this review study to describe the pathophysiology of inflammation of the appendix - contained in the hernia sac - and present the latest data about the diagnostic approach and surgical treatment of Amyand's hernia.

\section{KEYWORDS}

inguinal hernia; appendix; acute appendicitis; appendectomy; child

\section{AUTHOR AFFILIATIONS}

${ }^{1}$ Department of Internal Medicine, General Hospital of Veria, Veria, Greece

${ }^{2}$ 1st Department of Pediatric Surgery, Aristotle University of Thessaloniki, General Hospital “G. Gennimatas”, Thessaloniki, Greece

* Corresponding author: M. Alexandrou 3B, Peuka, Thessaloniki, Postal code 57010, Greece; e-mail: dipatoulias@gmail.com

Received: 14 March 2017

Accepted: 11 August 2017

Published online: 5 February 2018

Acta Medica (Hradec Králové) 2017; 60(3): 131-134

https://doi.org/10.14712/18059694.2018.7

(C) 2017 The Authors. This is an open-access article distributed under the terms of the Creative Commons Attribution License (http://creativecommons.org/licenses/by/4.0), which permits unrestricted use, distribution, and reproduction in any medium, provided the original author and source are credited. 


\section{DEFINITION AND HISTORY}

Amyand's hernia is defined as an inguinal hernia, containing the appendix within the hernia sac. In $1735 \mathrm{C}$. Amyand described the first case of incarcerated inguinal hernia, containing a perforated appendix, in an 11-year-old boy (1). The patient underwent simultaneous ligation of the hernia sac and appendectomy. Historically, it was the first conducted appendectomy (2). It should not be confused with femoral hernia containing the appendix. The latter was named De Garengeot hernia after Rene Jacques Croissant De Garengeot, who first described in 1731 a case of femoral hernia, containing a non-inflamed appendix $(1,3)$.

\section{EPIDEMIOLOGY}

It is more common in childhood, given that inguinal hernia is, mainly, caused by a persistent patent processus vaginalis (PPV). Amyand's hernia cases have been recorded in every age, from neonates to elderly (4). Amyand's hernia corresponds to $2 \%$ of all appendectomies, during neonatal period and infancy (5). It is, understandably, more frequent in males, due to the greater incidence of inguinal hernia, and right-sided (4). A left sided Amyand's hernia is usually the consequence of the mobile cecum syndrome and presence of sizeable appendix. However, in theoretical basis, it can be present on a background of situs inversus or malrotation (2, $3,5,6,7)$. In a review of 30 cases, 3 out of 30 were left-sided (8). According to Kinoo et al., only 15 left-sided Amyand's hernia cases were reported, until 2013 (2). Nicola et al. and Mahajan et al. described cases, in which Amyand's hernia was accompanied with the bladder, ovarian, fallopian tube, omentum or a Meckel diverticulum. Cecum is the organ that is most frequently contained within hernia $\operatorname{sac}(9,10)$. Additionally, in cases of complete appendiceal protrusion within the sac, at least a part of the cecum protrudes, as well.

\section{PATHOPHYSIOLOGY}

Amyand's hernia occurs in 1\% (0.19-1.7\%) of all inguinal hernia cases $(2,3,6,11)$. In $0.13 \%$ of all cases, the appendix is inflamed. It should be noted that appendiceal perforation leads to a dramatic increase of the mortality rate (15-30\%), due to severe abdominal sepsis $(2,3,6,12)$.

The incidence of acute appendicitis in the general population is $8 \%$, whereas- as mentioned above - incidence of appendicitis present in an inguinal hernia is reported to be $0.1 \%(12,13)$. The exact mechanism of appendicitis, within an inguinal hernia is not fully understood (5). After a thorough review of the existing literature, some opinions are reported below:

(1) Incarceration and, subsequently, inflammation of the appendix $(14,15)$.

(2) The presence of the appendix within the hernia sac predisposes for the development of adhesions between its serous membrane and the hernia sac, resulting in an irreducible hernia, susceptible to injury $(6,16)$.

(3) The contraction of anterolateral abdominal muscles leads to an increase in intra-abdominal pressure, causing compression and functional obstruction of the prolapsed appendix (17).

(4) Inflammatory swelling of the appendix may be the beginning of a vicious cycle. Thus, Amyand's hernia becomes irreducible, accentuating the swelling due to venous stasis and causing an impaired microcirculation of the appendix wall, resulting in bacterial overgrowth and translocation $(11,12)$.

\section{CLINICAL PRESENTATION}

This entity is usually asymptomatic, presenting with the typical symptoms of inguinal hernia in childhood (reducible - usually, automatically - bulge of the groin with local mild discomfort). In very rare cases, incarceration and obstruction of the appendix may be induced, resulting in acute appendicitis $(18,19)$. Given that the inflamed appendix is contained within the hernia sac, the symptoms of the appendicitis, in this case, are those of an irreducible or incarcerated inguinal hernia or, occasionally, of an acute scrotum ipsilaterally with the inguinal hernia, with accompaning symptoms such as pain in the right lower quadrant of the abdomen, anorexia, nausea and vomiting $(20,21,22)$. During physical examination, common findings include a painful, irreducible bulge in the groin area, accompanied with swelling of the overlying tissue and excessive redness of the overlying skin. Typically, McBurney sign is absent in those patients $(23,24)$. Differential diagnosis should include hydrocele, testicular torsion, inguinal lymphadenitis and epidydimo-orchitis (10).

\section{DIAGNOSIS}

In most cases, Amyand's hernia is diagnosed intra-operatively $(5,6,25)$. Sharma et al. treated 18 patients with Amyand's hernia, while no patient was diagnosed pre-operatively $(6,26)$. Cankormaz et al. treated 12 neonates and infants (median age $=40$ days) with Amyand's hernia, making the diagnosis pre-operatively in one out of twelve cases (22). Weber et al. performed a retrospective study of 60 Amyand's hernia cases, treated over 12 years, out of which the hernia was diagnosed in only one of them (14).

In certain cases, the performance of imaging -such as ultrasound or computed tomography (CT) could provide useful information substantial for preoperative diagnosis $(6,27)$. Okur et al. studied 21 Amyand's hernia cases, performing a preoperative ultrasound in $12 / 21$ cases (57.1\%) and diagnosing the hernia in 9/12 (75\%) of them (11).

Most surgeons do not recommend imaging examination in the context of preoperative evaluation, in order to proceed with surgical repair of an inguinal hernia, especially when there is indication of prompt therapeutic intervention. We believe that a symptomatic incarcerated or difficultly reducible inguinal hernia should be investigated via imaging studies, aiming at increasing the number of complicated Amyand's hernia cases being preoperatively diagnosed.

The most significant ultrasound finding is the presence of a non-compressible tubular structure within the hernia sac. In case of appendicitis, additional features include wall thickening and hyperemia $(20,28)$. 
The primary CT signs considered as pathognomonic for Amyand's hernia are a blind ending tubular structure inside the hernia sac, arising from the base of the caecum, wall thickening, hyperemia and periappendiceal fat stranding $(12,20)$.

\section{THERAPEUTIC STRATEGY}

Losanoff and Basson proposed a classification for Amyand's hernia, setting a therapeutic framework (Table 1) $(20,29,30,31)$.

Tab. 1: Losanoff and Basson classification of Amyand's hernia.

\begin{tabular}{|l|l|l|}
\hline Classification & Description & Management \\
\hline Type 1 & $\begin{array}{l}\text { Normal appendix in an } \\
\text { inguinal hernia }\end{array}$ & $\begin{array}{l}\text { Hernia reduction, } \\
\text { mesh replacement }\end{array}$ \\
\hline Type 2 & $\begin{array}{l}\text { Acute appendicitis in } \\
\text { an inguinal hernia with } \\
\text { no abdominal sepsis }\end{array}$ & $\begin{array}{l}\text { Appendectomy, } \\
\text { primary no prosthetics } \\
\text { hernia repair }\end{array}$ \\
\hline Type 3 & $\begin{array}{l}\text { Acute appendicitis } \\
\text { in an inguinal hernia } \\
\text { with abdominal and } \\
\text { abdominal wall sepsis }\end{array}$ & $\begin{array}{l}\text { Laparotomy, appen- } \\
\text { dectomy, and primary } \\
\text { no prosthetic hernia } \\
\text { repair }\end{array}$ \\
\hline Type 4 & $\begin{array}{l}\text { Acute appendicitis in } \\
\text { an inguinal hernia with } \\
\text { abdominal concomi- } \\
\text { tant pathology }\end{array}$ & $\begin{array}{l}\text { Same as type 3 plus } \\
\text { management of con- } \\
\text { comitant disease }\end{array}$ \\
\hline
\end{tabular}

Tab. 2: Classification of Amyand hernia after Rikki modification.

\begin{tabular}{|c|c|c|}
\hline Classification & Description & Management \\
\hline Type 1 & $\begin{array}{l}\text { Normal appendix in an } \\
\text { inguinal hernia }\end{array}$ & $\begin{array}{l}\text { Hernia reduction, } \\
\text { mesh replacement }\end{array}$ \\
\hline Type 2 & $\begin{array}{l}\text { Acute appendicitis in } \\
\text { an inguinal hernia with } \\
\text { no abdominal sepsis }\end{array}$ & $\begin{array}{l}\text { Appendectomy, } \\
\text { primary no prosthetics } \\
\text { hernia repair }\end{array}$ \\
\hline Type 3 & $\begin{array}{l}\text { Acute appendicitis in } \\
\text { an inguinal hernia with } \\
\text { peritoneal and/or } \\
\text { abdominal wall sepsis }\end{array}$ & $\begin{array}{l}\text { Laparotomy, appen- } \\
\text { dectomy, and primary } \\
\text { no prosthetic hernia } \\
\text { repair }\end{array}$ \\
\hline Type 4 & $\begin{array}{l}\text { Acute appendicitis in } \\
\text { an inguinal hernia with } \\
\text { abdominal concomi- } \\
\text { tant pathology }\end{array}$ & $\begin{array}{l}\text { Same as type } 3 \text { plus } \\
\text { management of con- } \\
\text { comitant disease }\end{array}$ \\
\hline Type 5a & $\begin{array}{l}\text { Normal appendix } \\
\text { within an incisional } \\
\text { hernia }\end{array}$ & $\begin{array}{l}\text { Hernia reduction, } \\
\text { primary repair of } \\
\text { hernia including mesh } \\
\text { replacement }\end{array}$ \\
\hline Type 5b & $\begin{array}{l}\text { Acute appendicitis } \\
\text { within an incisional } \\
\text { hernia without peri- } \\
\text { tonitis }\end{array}$ & $\begin{array}{l}\text { Appendectomy } \\
\text { through hernia, } \\
\text { primary closure of } \\
\text { the aponeurotic gap, } \\
\text { no prosthetics hernia } \\
\text { repair }\end{array}$ \\
\hline Type 5c & $\begin{array}{l}\text { Acute appendicitis } \\
\text { within an incisional } \\
\text { hernia with peritonitis } \\
\text { or abdominal wall } \\
\text { sepsis or in relation to } \\
\text { previous surgery. }\end{array}$ & Management as type 4 \\
\hline
\end{tabular}

Singal et al. refer to the modification of the Losanoff and Basson classification of Amyand's hernia, also known as Rikki modification. A fifth type of Amyand's hernia is added on the latter classification, referred as an incisional hernia through which the vermiform appendix protrudes. This type is divided into three subtypes, $5 \mathrm{a}, 5 \mathrm{~b}$ and $5 \mathrm{c}$ (Table 2) (30).

As a general rule, in case of a non-inflamed appendix, the patient undergoes hernia repair without appendicectomy $(12,19,22,31)$. Researchers sharing this opinion believe that this approach could decrease postoperative complications, as a clean surgery is not converted to a clean-contaminated one. Besides, the appendix could be used, in the future, for replacement of the extra-hepatic biliary tract, urinary diversion or appendicostomy (Malone procedure) $(9,33)$. Furthermore, during appendicectomy, surgical manipulations in the base of the caecum could increase the recurrence rate of the inguinal hernia, due to detachment in the deep inguinal ring (32). It should be noted that surgical manipulations involving the appendix could trigger secondary acute inflammation $(32,33)$. This - theoretical possibility is minimized, when the procedure is performed laparoscopically $(9,33)$. Shaknovsky et al. refer to the successful treatment of an adult patient with Amyand's hernia type I, after application of Robotic platform Da Vinci Surgical System' 3D HD imaging (34).

Exception to this rule is an non-inflamed appendix contained in a left-sided Amyand's hernia, where preventive appendectomy is recommended, as, in case of a future appendicitis, there is a high risk of false or delayed diagnosis or even resistive surgical procedure $(8,12,35)$.

We believe that algorithmic approach of Amyand's hernia, as described in schema 1 , is a safe guide as for choice of the appropriate therapeutic strategy (Schema 1).

\section{ACKNOWLEDGEMENTS, FUNDING AND DISCLOSURES}

All the authors contributed equally to the writing of this short review article. None of the contributing authors have any conflict of interest, including specific financial interests or relationships and affiliations relevant to the subject matter or materials discussed in the manuscript.

\section{REFERENCES}

1. Amyand C. Of an inguinal rupture, with a pin in the appendix coeci, incrusted with stone, and some observations on wounds in the guts. Philosophical Transactions 1835; 39: 1735-6.

2. Mewa Kinoo S, Aboobakar MR, Sigh B. Amyand's hernia: A serendipitous diagnosis. Case Report in Surg Volume 2013; Article ID 125095.

3. Morales-Cardenas A, Ploneda-Valencia CF, Sainz-Escarrega VH, et al. Amyand hernia: Case report and review of the literature. Ann Med Surg 2015; 4:113-5.

4. Ivashuk G, Cesmebasi A, Sorenson EP, Blaak C, Loukas M, Tubbs SR. Amyand's hernia: a review. Med Sci Monit 2014; 28(20): 140-6.

5. Gupta S, Sharma R, Kaushik R. Left sided Amyand's Hernia. Singapore Med J 2005; 46(8): 424-5.

6. Hiatt JR, Hiatt N. Amyand's Hernia. N Engl J Med 1988; 318(21): 1402 .

7. Losanoff JE, Basson MD. Amyand Hernia: what lies beneath a proposed classification scheme to determine management. Am Surg 2007; 73(12): 1288-90. 


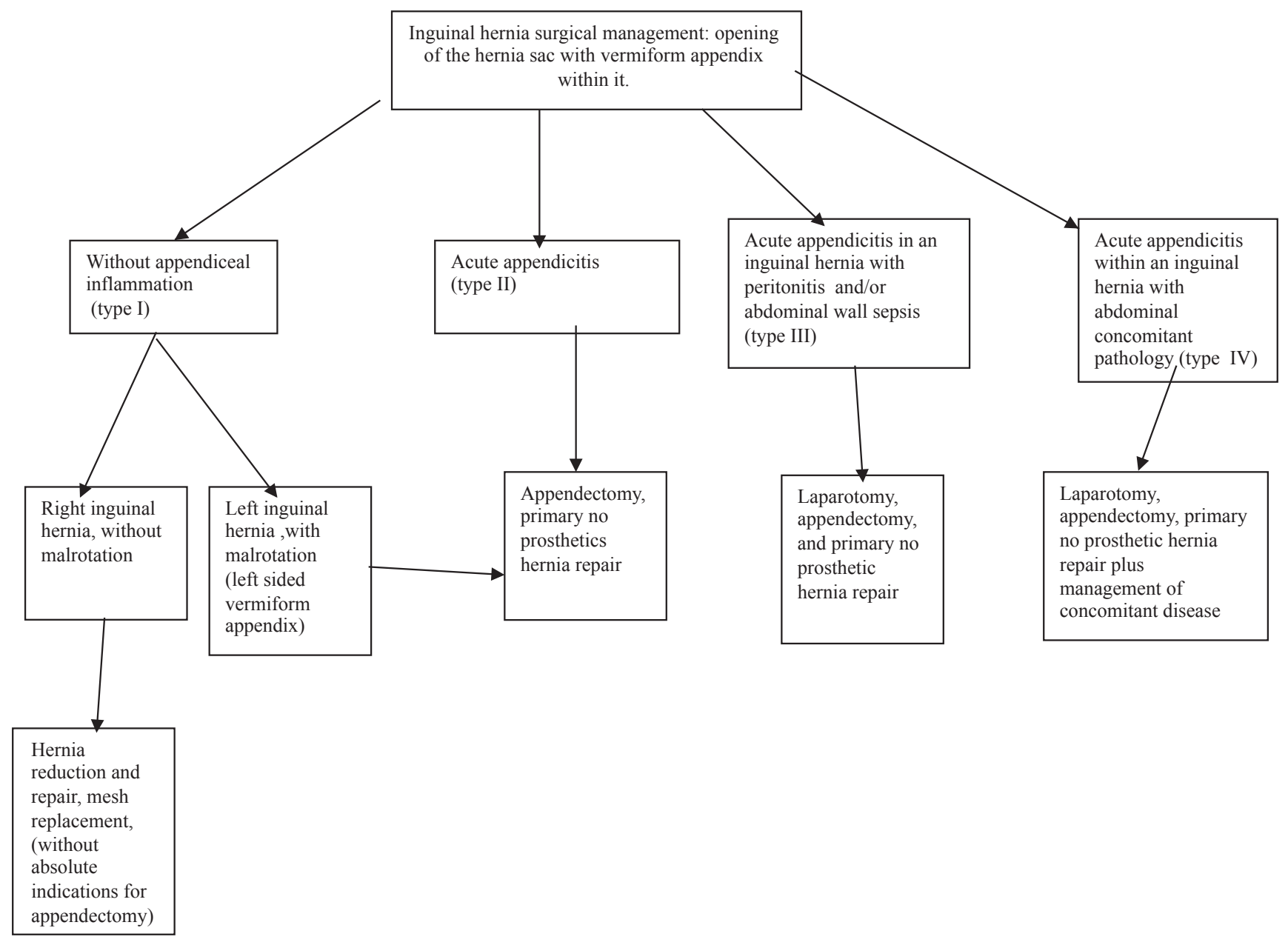

Schema 1: Algorithmic therapeutic approach of Amyand's hernia.

8. Holmes M, Ee M, Fenton E, Jones N. Left Amyand's hernia in children: method, management and myth. J Pediatr Child Health 2013; 49(9): 789-90.

9. Nikola SM. Hernia de Amyand: presentacion de un caso y revision de la literature. Rev Chil Cirugia 2007; 59(2): 142-4.

10. Mahajan A, Pawar P, Luther A, Haque P. Right sided Amyand's hernia: a rare case report. Int Surg J 2014; 1(1): 43-4.

11. Okur MH, Karacay S, Uygun I, Topc K, et al. Amyand's hernias in childhood (a report on 21 patients): a single-centre experience. Pediatr Surg Int 2013; 29(6): 571-4.

12. Singhal S, Singhal A, Singh Negi S, et al. Amyand's hernia: rare presentation of a common ailment. Case Reports in Gastrointestinal Medicine 2015 Volume 2015; Article ID 629127.

13. Sengul I, Sengul D, Aribas D. An elective detection of an Amyand's hernia with an adhesive caecum to the sac: report of a rare case. North Am J Med Sciences 2011; 3(8): 391-3.

14. Weber RV, Hunt ZC, Kral JC. Amyand's hernia. Etiologic and therapeutic implications of two complications. Surg Rounds 1999; 22: 552-6.

15. Ash L, Hatem S, Ramirez GA, Veniero J. Amyand's hernia: a case report of prospective ct diagnosis in the emergency department. Emerg Radiol 2005; 11(4): 231-2.

16. Abu-Dalu J, Urca I. Incarcerated inguinal hernia with a perforated appendix and periappendicular abscess: report of a case. Dis Colon Rectum 1972; 15(6): 464-5.

17. Solecki R, Matyja A, Milanowski W. Amyand's hernia: a report of two cases. Hernia 2003; 7(1): 50-1.

18. Hotiana MM, Kundu S, Ahmad I. Complicated inguinal hernia of Amyand. South Med J. 2007; 100(4): 411.

19. Nigri G, Costa G, Valabrega S, et al. A rare presentation of Amyand's hernia. Case report and review of the literature. Minerva Chir 2008; 63(2): 169-74.

20. Okur MH, Arslan MA, Zeytun H, Otcu S. Amyand's hernia complicated with acute appendicitis: A case report and literature review. Ped Urol Case Rep 2015; 2(4): 7-12.

21. Quartey B, Ugochukwu O, Kuehn R, Ospina K. Incarcerated recurrent Amyand's hernia. J Emerg Trauma Shock 2012; 5(4): 344-6.
22. Cankorkmaz L, Ozer H, Guney C, et al. Amyand's hernia in the children: a single center experience. Surgery 2010; 147(1): 140-3.

23. Fernando J, Leelaranta S. Amyand's hernia. Ceylon Med J 2002; 2: Article 71.

24. Laermans S, Aerts P, De Man R. Amyand's hernia: inguinal hernia with acute appendicitis. J de Belge de Radiologie 2007; 90(6): 524-5.

25. Green J, Gutwein LG. Amyand's hernia: a rare inguinal hernia. JSCR 2013; 9: 140-6.

26. Sharma H, Gupta A, Shekhawat NS, Memon B, Memon MA. Amyand's hernia: a report of 18 consecutive patients over a 15-year period. Hernia 2007; 11(1): 31-5.

27. Michalinos A, Moris D, Vernadakis S. Amyand's hernia: a review. Am J Surg 2014; 207(6): 989-95.

28. Tsang WK, Lee KL, Tam KF, et al. Acute appendicitis complicating Amyand's hernia: imaging features and literature review. Hong Kong Med J 2014; 20(3): 255-7.

29. Dange A, Gireboinwad S. A rare case of Amyand's hernia presenting in a 3-year-old male child. Indian J Surg 2013; 75(4): 332-3.

30. Singal R, Mittal A, Gupta S, Sahu P, Sekhon MS. An incarcerated appendix: report of three cases and a review of the literature. Hernia 2012; 16(1): 91-7.

31. Jabloun A, Bouthour H, Bustame S, et al. Amyand's hernia with appendicitis in the children: A delayed diagnosis. J Pediatr Surg Case Reports 2016; 13: 6-7.

32. Livaditi E, Mavridis G, Christopoulos Geroulanos G. Amyand's hernia in premature neonates: report of two cases. Hernia 2007; 11(6): $547-9$.

33. Ofili OP. Spontaneous appendectomy and inguinal herniorraphy could be beneficial? Ethiopian Med J 1991; 29(1): 37-8.

34. Shaknovsky TJ, Sabido F, Shaikh D, Rosen P. Robotic repair of Amyand's hernia; a case report. J Case Rep Images Surg 2016; 2: 92-96.

35. Johari HG, Paydar S, Zeraatian S, Davani N, et al. Left sided Amyand hernia. Annals of Saudi Med 2009; 29(4):321-2. 